\begin{tabular}{l|c|c|}
\hline & International Journal of Current Research in \\
Biosciences and Plant Biology \\
EXCELLENT \\
PUBLISHERS
\end{tabular}

Original Research Article

doi: https://doi.org/10.20546/ijcrbp.2018.505.002

\title{
Distribution and Eco-Biological Research of Lathyrus Species in Azerbaijan
}

\author{
G. F. Allahverdiyeva* and A. M. Asgarov \\ Genetic Resources Institute of ANAS, Baku, Azerbaijan, Azadliq ave. 155, Baku, AZ 1106
}

${ }^{*}$ Corresponding author.

\begin{tabular}{|c|c|}
\hline Article Info & ABSTRACT \\
\hline $\begin{array}{l}\text { Date of Acceptance: } \\
20 \text { April } 2018\end{array}$ & \multirow{4}{*}{$\begin{array}{l}\text { As a result of monitoring conducted in nature in the years 2015-2017, more than } 150 \\
\text { copies of herbarium materials and seeds were collected covering } 35 \text { populations on } 12 \\
\text { species of Lathyrus. The article presents the results of the research on biomorphological } \\
\text { diversity and dissemination based on their descriptor data. The biomorphological } \\
\text { variability and ecological features of the } 12 \text { species that have been accumulated } \\
\text { dispersed in different regions of Azerbaijan and in various ecological conditions have } \\
\text { shown that these species are more commonly found in the Greater Caucasus, } \\
\text { Kura - Araz and Talysh botanic - geographical regions. They are dispersed mostly in } \\
\text { the forests and subalpine meadows. }\end{array}$} \\
\hline $\begin{array}{l}\text { Date of Publication: } \\
06 \text { May } 2018\end{array}$ & \\
\hline Keywords & \\
\hline $\begin{array}{l}\text { Lathyrus L. } \\
\text { Eco-botanical } \\
\text { Biomorphology } \\
\text { Cluster analysis }\end{array}$ & \\
\hline
\end{tabular}

\section{Introduction}

Lathyrus L. is one of the polymorphic varieties of legumes. Lathyrus species are precious fodder, medicinal and ornamental plants, contains a large number of proteins and other biologically active substances, and also are beneficial as fodder plants. Sweet pea (L. odoratus) is widely used as a decorative plant. Some types of species are beehoney (Sarker et al., 1997). Meadow vetchling (L. pratensis) is a herbal plant (Grossheim, 1952; Karyagin, 1954).

Researchers divide 170 species of Lathyrus L. into (Kenicer, 2008; Lewis et al., 2005) 12 to 13 sections throughout the world (Chefranova, 1971, 1987; Asmussen and Liston, 1988; ILDIS, 2010; Kupicha, 1974, 1983; Leht, 2009). Kupicha (1979) in "The taxonomic studies in the tribe Vicieae (Leguminosae)" included this genus into Vicieae tribe and informed of 13 sections of this genus.

Chefranova (1987) in "The Flora of Euro. part of the USSR" divided the Lathyrus genus into 6 subgenus and 15 sections. Shehadeh (2011) in his work, "Ecogeographic, genetic and taxonomic" taking into account the molecular signs and the genetic analysis, divided the world-wide distributed Lathyrus genus into 9 sections. 
Lathyrus is distributed with 52 species in Europe, 30 species in North America, 78 species in Asia and 24 species in tropical East Africa and South America. Earlier five of the Lathyrus species spread in Azerbaijan were referred to as Orobus L. (Grossheim, 1952; Karyagin, 1954), which is currently not regarded as an independent species and is included in the composition of the Lathyrus species (Asgarov, 2011, 2016; Magulaev, 2005). Unlike the Lathyrus species, in Orobus L. species, the leaves are without tendril, and instead of it, there is a protrusion at the end of the leaf. This sign is now regarded as the main characteristic of the Lathyrus species referred to the Orobus section (Asgarov, 2011, 2016; Grossheim, 1952; Fedchenko, 1948; Chefranova, 1971, 1987; Asmussen and Liston, 1998). Currently, Orobus genus of this plant with 24 species is found wild in Azerbaijan (Asgarov, 2011, 2016; Karyagin, 1954). One species is cultivated (L. odoratus).

Though Grossheim (1952) gave information about the types of Lathyrus spread throughout the Caucasus and Karyagin (1954), Asgarov (2011, 2016) and other botanists in species spread in Azerbaijan in their works, the biomorphological diversity of the species, its intrinsic systematics have not been studied extensively.

Lathyrus species are annual and perennial herbs. Stem erect or climbing by means of tendrils. The leaves are composed of one or several leaflets, and ending in tendril; a leaflet is elliptic, ovate, ovate oblong, lancet or linear; veins parallel or pinnate. Leaves occasionally phyllodic or reduced to stipules and a tendril. Inflorescence racemose, 1 or many flowered. Calyx campanulate, unequally or equally toothed. Corolla is dark red, pink, yellow or white, sometimes purple, brick red, or orange. Staminal tube usually truncates at apex, rarely oblique. Ovary is bare, sometimes flat or glandular and haired. Legume is linear, elliptic, polysemous, aside squeezed, and opened. Seeds 2 to many (Cherepanov, 1995; Davis, 1979; Maxted and Goyder, 1988; Bojnansky and Fargasova, 2007; Yakovlev et al., 1996).
Cytological investigations have shown that all species in Azerbaijan were diploid with $2 n=14$ chromosomes, the basic chromosome number of $\mathrm{x}=7$ (Shehadeh, 2011; Leht, 2009; Badr, 2007; Sarker et al., 1997; Bojnansky and Fargasova, 2007; Yakovlev et al., 1996; Yamamoto et al., 1984).

\section{Materials and methods}

The materials for the study were collected during expeditions under the leadership of A. M. Asgarov at the Institute of Genetic Resources during 2015-17. Herbarium data and extensive literature information have also been analyzed. Comparative morphological, botanical - geographical, biomorphological, ecological, taxonomic, floristicsystematic, phytocenological methods were used in the study. In addition, the materials stored in the Herbarium Foundation of the Botanical Institute of ANAS and the Herbarium Foundation of the Institute of Genetic Resources of ANAS were investigated. The spreading of species has been given on the regionalization scheme adopted in the flora of Azerbaijan.

Information about temperature and precipitation on routes is based on climatic indicators in the Diva GIS computer program. The gathering coordinates were recorded with Garmin eTrex 20-model GPS. Cluster analysis was performed through the SSPS Win (SPSS version 16.0) program.

Asgarova's (2011, 2016) classification was used for species nomenclature, and Raunkier (1937) and Serebryakov's (1964) classifications were used while analyzing life forms and other ecological features.

\section{Results and discussion}

Thirty five stations located in different areas selected by certain echo-geographical features from one-another were selected for exploration of the Lathyrus species dispersed in Azerbaijan in 20152017 , the ranges of the species were mapped with the DIVA-GIS computer program (Fig. 1). Lathyrus 
species were collected in different biotopes: forest, meadow, planting area, in grass, river coast, roadside. The ecological and geographical data of the Lathyrus species collected from the research area - data about latitude and longitude, sea level are given in Table 1.

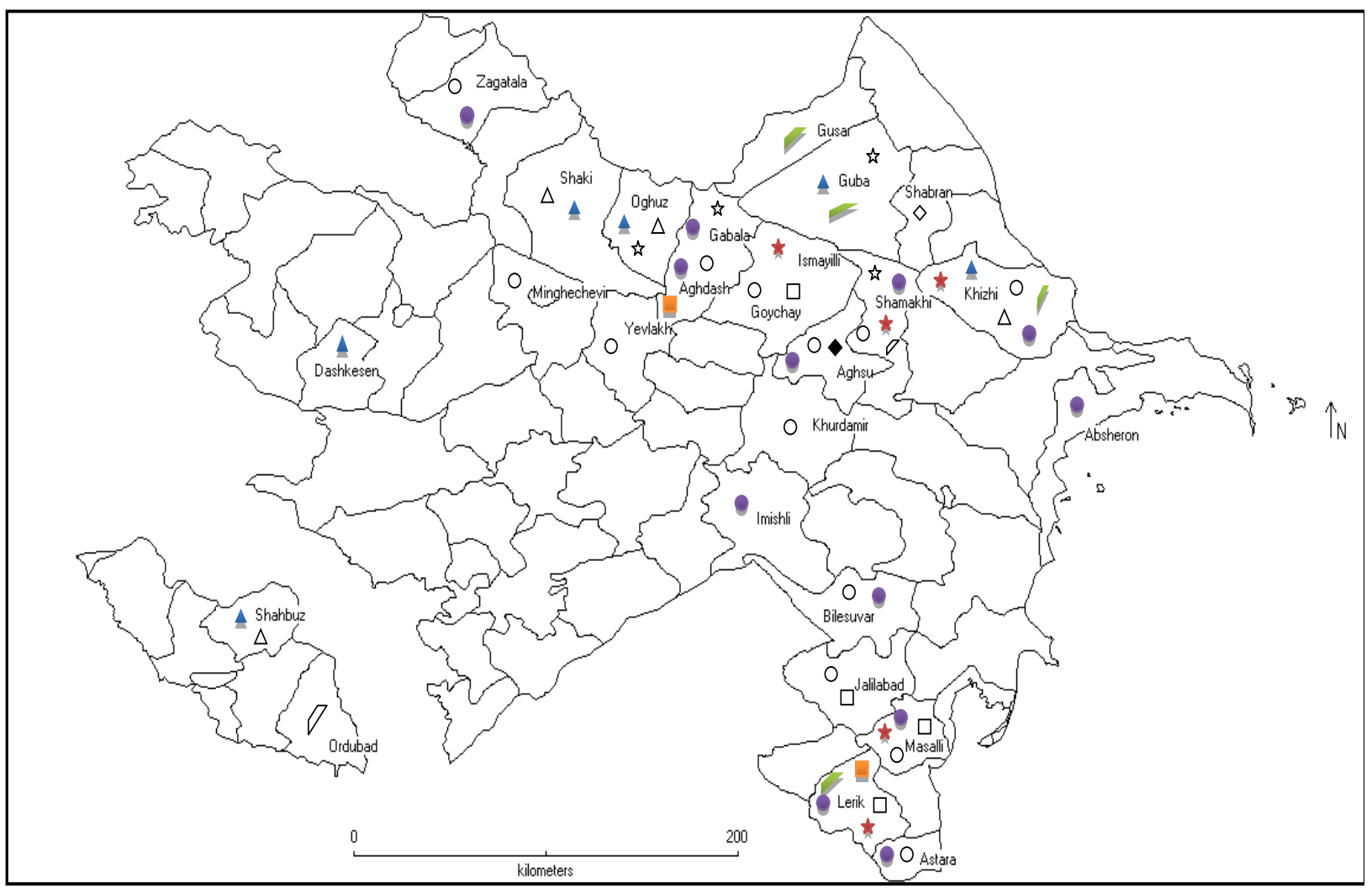

Fig. 1: Areas of distribution of species which herbarium and seeds are collected: $\bigcirc-L$. aphaca; - L. hirsutus; $\triangle-L$. miniatus; $\triangle$-L.pratensis; $;$ - L. tuberosus; - L. sphaericus; - L. cicera; $\square$ - L.annuus; $=$ L. laxiflorus; $\checkmark$ - L. cyaneus; $\diamond$-L. roseus; $>$ L. pallescens.

Different herbarium samples collected by use for the fenetic (taximetric) analysis of Lathyrus types were reviewed. At least five examples of each population have been studied and each population is labeled as the single Operational Taxonomic Unit (OTU). For the morphological analysis of plants, 31 quantities (height of plant, length of leafstalk, number, length and width of leaflets, number of flowers in flower group, length of flower group, length of corolla, number, length and width of legymes, number of seeds, diameter of seed) and quality (ecobiomorph of the plant, shape, form, surface of the stem, base of the leaf stalk, structure, shape of the leaflet, stipule shape, shape of the flower, flower group layout, form of the calyx, colour of the corolla, form, structure and colour of the seed) like signs have been selected.
The measurements were made at least 2-3 copies of each population, and the average value was calculated. Based on the results obtained, the taximetric (fenetic) analysis was carried out using the method of Cluster Analysis (CA). The analyzes were conducted through the SSPS Win (SPSS version 16.0) software. The types of morphological quantitative and qualitative signs used in the research are classified into clusters. Six clusters 33 consisting of 12 species were identified during the 34 research (Fig. 2).

The statistical analysis of the above-mentioned species of Lathyrus genus collected during the expeditions in 2015-2017 has been conducted and it has been found out that there is a negative correlation between altitude - minimum, maximum 
and average - annual temperature indicators with $1 \%$ probability. A positive correlation has been recorded between the altitude and precipitation with 5\% probability. A negative correlation was observed between precipitation and average annual temperature indicators with $5 \%$ probability. Also, there was a positive correlation between the minimum temperature and the maximum temperature and average annual temperature and between the maximum temperature and the average annual temperature with $1 \%$ probability (Table 2 ). The first cluster includes L. cyaneus, L. pallescens, L. sphaericus collected from the different populations, the second cluster includes L. laxiflorus, L. roseus, L. cicera, L. annuus, the third cluster includes $L$. pratensis, L. tuberosus, the fourth cluster includes $L$. aphaca, the fifth cluster includes $L$. miniatus, and the sixth cluster includes L. hirsutus.

The first cluster is divided into 4 subclusters: the first subcluster includes L. cyaneus (Shamakhi and Ordubad regions), the second subcluster includes $L$. pallescens (Shamakhi region, Aghsu road). These species belong to the section Lathyrostylis (Shehadeh, 2011; Kupicha, 1974). The third subcluster includes L. sphaericus (Aghdash, Khizi, Masalli regions), the fourth subcluster includes $L$. sphaericus (Lerik region) species. This species belongs to Lineacarpus section (Shehadeh, 2011; Kupicha, 1974). The species belonging to Lathyrostylis and Lineacarpus are grouped into one cluster.

The species studied belong to morphological and ecological groups. $L$. pallescens is xeromesophyte, $L$. cyaneus, L. sphaericus are mesophytes. The species belonging here also belong to various ecobiomorphs. Thus, L. cyaneus, L. pallescens are perennial; $L$. sphaericus is annual plant (Serebryakov, 1964). They were existed at the low and middle mountain range during the expeditions (Prilipko, 1954). There are four climatic types: mild-hot with dry summers, mild winters and dry, warm - hot semi-desert and dry desert climate with dry summers, cold climate with dry summers. In these areas, the types of soil (clay, sandy- clay), the inclination rate of the slope (L 2 flat $0^{0}-3^{0}$; O 5- mountainous $30-45^{0}$; E 6- steep slope $>45^{\circ}$ ) are noted.

The second cluster is divided into 4 subclusters: the first subcluster includes L. laxiflorus (Lerik, Guba, Khizi regions), the second subcluster includes $L$. roseus (Shabran region), and the third subcluster includes L. cicera (Aghdash region, Kerik region Galasar, Mistan village) and L. annuus (Goychay, Masalli regions). L. laxiflorus is included in the Pratensis section, L. roseus - Orobon section, $L$. cicera, L. annuus - Lathyrus section (Shehadeh, 2011; Kupicha, 1974).

Table 1. Coordinates of Lathyrus species found and ecological information on them.

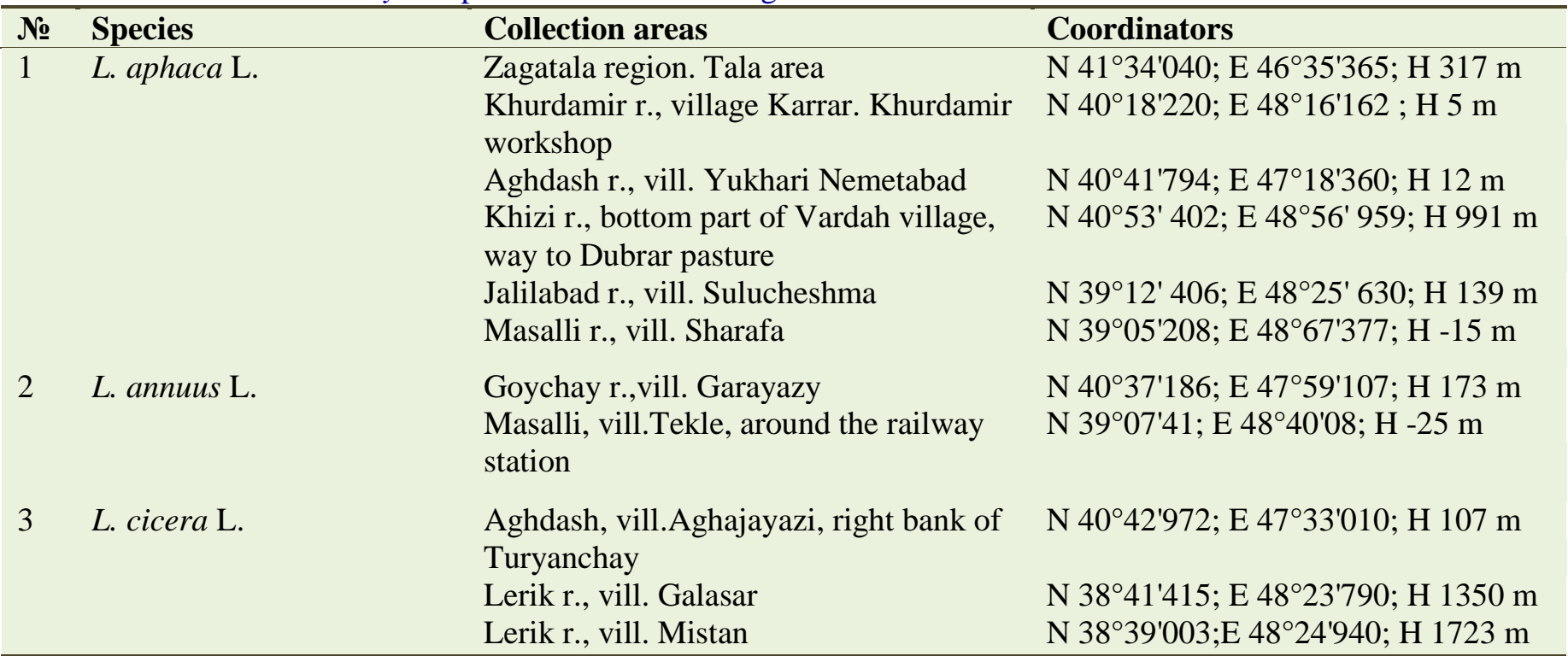




\begin{tabular}{|c|c|c|c|}
\hline № & Species & Collection areas & Coordinators \\
\hline 4 & L. sphaericus Retz. & $\begin{array}{l}\text { Aghdash, vill.Aghajayazi, right bank of } \\
\text { Turyanchay } \\
\text { Khizi r., bottom part of Vardah village, } \\
\text { way to Dubrar pasture } \\
\text { Shamakhi r., vill. Pirgulu } \\
\text { Masalli, vill. Shikhlar, around the } \\
\text { Vilash river } \\
\text { Lerik r., vill. Shovu }\end{array}$ & 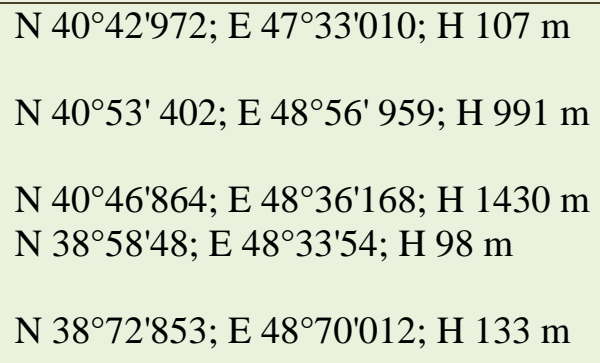 \\
\hline 5 & L. cyaneus (Stev.) C. Koch & $\begin{array}{l}\text { Shamakhi r., vill. Mirzandiya } \\
\text { Ordubad r., vill. Paragha }\end{array}$ & $\begin{array}{l}\text { N } 40^{\circ} 34^{\prime} 737 ; \text { E } 48^{\circ} 43^{\prime} 648 ; \text { H } 584 \text { m } \\
\text { N } 39^{\circ} 5^{\prime} 10 ; \text { E } 45^{\circ} 55^{\prime} 13 ; \text { H } 1644 \text { m }\end{array}$ \\
\hline 6 & $\begin{array}{l}\text { L. pallescens (Bieb) C. } \\
\text { Koch }\end{array}$ & Shamakhi r., Aghsu road & N 40³8'550; E 48²8'450; H 794 m \\
\hline 7 & L. roseus Stev. & Shabran r., vill. Zeyna & N 410' 922; E 4841' 120; H 935 m \\
\hline 8 & $\begin{array}{l}\text { L. laxiflorus (Desf) O. } \\
\text { Kuntze }\end{array}$ & $\begin{array}{l}\text { Lerik r., entrance of vill. Piran } \\
\text { Khizi r., bottom part of Vardah village, } \\
\text { way to Dubrar pasture } \\
\text { Guba r., vill. Digah }\end{array}$ & 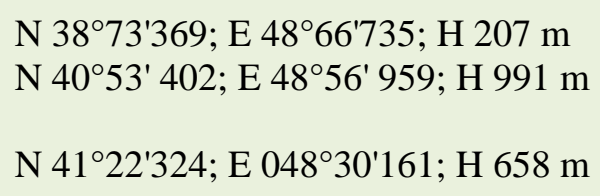 \\
\hline 9 & L. pratensis L. & $\begin{array}{l}\text { Oghuz r., vill. Dashaghil } \\
\text { Shamakhi r., vill. Pirgulu } \\
\text { Khizi r., territory of Chistiy-Klyuch } \\
\text { Shahbuz r., Batabat pasture, } \\
\text { surrounding of Lake Batabat }\end{array}$ & 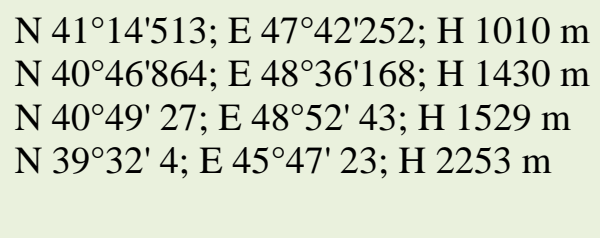 \\
\hline 10 & L. tuberosus L. & $\begin{array}{l}\text { Oghuz r., vill. Khalkhal } \\
\text { Shamakhi r., vill. Pirgulu } \\
\text { Shamakhi r., Aghsu road } \\
\text { Gabala r.,vill. Yenikend } \\
\text { Guba r. vill. Vladimirovka }\end{array}$ & 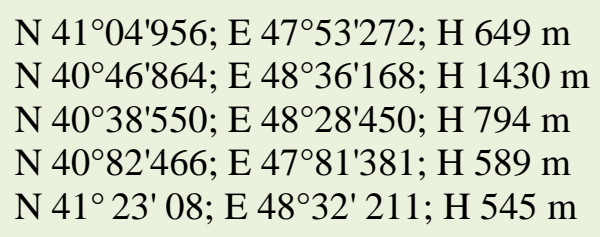 \\
\hline 11 & L. miniatus Bieb ex Stev. & $\begin{array}{l}\text { Khizi r., bottom part of Vardah village, } \\
\text { way to Dubrar pasture } \\
\text { Dashkesen r., vill.Khoshbulag } \\
\text { Shaki r., vill.Khish } \\
\text { Shahbuz r., Batabat pasture, } \\
\text { surrounding of Lake Batabat } \\
\text { Absheron r., Institute of Agriculture } \\
\text { Khizi r., bottom part of Vardah village, } \\
\text { way to Dubrar pasture } \\
\text { Bilasuvar r., Bilasuvar - Iran highway } \\
\text { territory of Imishli region } \\
\text { Zagatala r. Tala area } \\
\text { Lerik r., vill. Galasar }\end{array}$ & 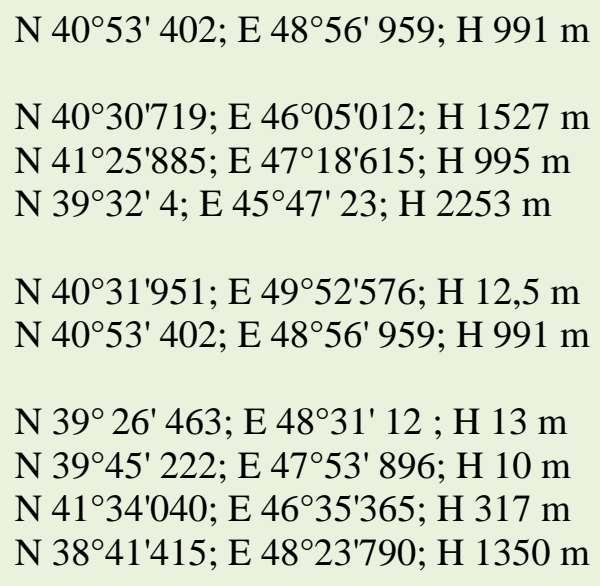 \\
\hline 12 & L. hirsutus L. & $\begin{array}{l}\text { Gabala r., vill. Kichik Amili } \\
\text { Aghdash r., vill.Yukhari Nemetabad } \\
\text { Shamakhi r.,Aghsu road } \\
\text { Masalli, vill.Tekle, around the } \\
\text { railwaystation } \\
\text { Masalli r.,vill.Gizilaghaj. } \\
\text { Zardab r., the edge of Aghjabedi road }\end{array}$ & 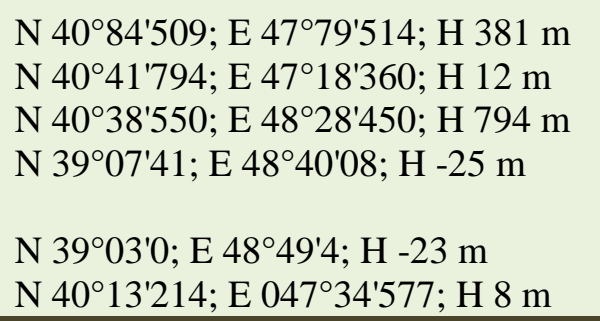 \\
\hline
\end{tabular}


Table 2. Correlation between ecological parameters of the collected samples.

\begin{tabular}{llllll}
\hline Signs & Altitude & Average & $\mathbf{T}_{\min }$ & $\mathbf{T}_{\max }$ & $\mathbf{T}_{\mathbf{o i}}$ \\
\hline Altitude & 1 & - & - & - & - \\
Average & $0.354^{*}$ & 1 & - & - & - \\
$\mathrm{T}_{\min }$ & $-0.903^{* *}$ & -0.167 & 1 & - & - \\
$\mathrm{T}_{\max }$ & $-0.862^{* *}$ & -0.3 & $0.883^{* *}$ & 1 & - \\
$\mathrm{T}_{\mathrm{oi}}$ & $-0.862^{* *}$ & $-0.346^{*}$ & $0.856^{* *}$ & $0.932^{* *}$ & 1 \\
\hline
\end{tabular}

$*$ - correlation is significant at the 0.05 level $(1-$ tailed $) ; * *$ - correlation is significant at the level $(1-$ tailed $)$

The species included in the second cluster are mesophytes. The species belonging here belong to different ecobiomorphs. Thus, $L$. laxiflorus, $L$. roseus are perennial, L. cicera, L. annuus - annual plants (Serebryakov, 1964). These species are found in the low and middle mountain ranges (Prilipko, 1954). There are 6 climatic types in this cluster: hot semi-desert and dry desert climate, mild - hot, humid cold and mountain tundra climate, mild-hot in which precipitation is equally distributed, mild-hot semi-desert and dry subtropical climate with dry summers, moderate and dry subtropical. Here the types of soil (clay, sandy, sandy- clay, gravel), the inclination rate of the slope (L 2 - flat $0^{0}-3^{0}$, U 3 - wavy $3^{0}-8^{0}$; O 5mountainous $30-45^{0}$; E 6- steep slope $>45^{\circ}$ ) are indicated.

The third cluster is divided into 4 subclusters: The first subcluster includes $L$. pratensis (Oghuz, Shamakhi, Khizi regions), the second subcluster includes L. pratensis (Shahbuz region), the third subcluster includes L. tuberosus (Oghuz, Shamakhi regions) and the fourth subcluster includes $L$. tuberosus (Aghsu, Gabala, Guba regions). $L$. pratensis is included into Pratensis section, and $L$. tuberosus is included into Lathyrus section (Shehadeh, 2011; Kupicha, 1974).

L. tuberosus belonging to the third cluster is xeromesophyte, L. pratensis - mesophyte. These species are perennials (Serebryakov, 1964). They are found mostly in the middle and low mountain ranges (Prilipko, 1954).Here 5 climatic types exit: semi-desert and dry desert climate, mild-hot with dry summers, hot, cold and mountain tundra climate in which precipitation is equally distributed, dry subtropical climate. In these areas, the types of soil (sandy, sandy- clay), the inclination rate of the slope (O 5- mountainous $30-45^{\circ}$; E 6- steep slope $>45^{\circ}$ ) are noted.

IV cluster is divided into 3 subclusters: the first subcluster includes L. aphaca (Khurdamir, Agdash regions), the second subcluster includes $L$. aphaca (Khizi, Masalli, Zagatala regions), and the third subcluster includes L. aphaca (Zagatala region). $L$. aphaca species is included in the Aphaca section, which has the least species in the taxonomic classification (Shehadeh, 2011; Kupicha, 1974).

This species is mesophyte and annual plant (Serebryakov, 1964). During the expedition, it was found in the low mountain range (Prilipko, 1954). There are 3 climatic types in this cluster: mild - hot semi-desert, mild - hot and subtropical, mild - hot climate with dry summers. In these areas, the types of soil (clay, sandy-clay), the inclination rate of the slope (L 2 - flat $0^{0}-3^{0}$; O 5- mountainous $30-45^{0}$ ) are noted.

The fifth cluster is divided into two subclusters: the first subcluster includes L. miniatus (Khizi, Dashkesen, Shahbuz regions) and the second subcluster includes L. miniatus (Shaki region). $L$. miniatus species is included in the Lathyrus section (Shehadeh, 2011; Kupicha, 1974).

L. miniatus belonging to this cluster is mesophyte. L. miniatus species is perennial (Serebryakov, 1964). This species is found in middle and high mountain ranges (Prilipko, 1954). Here 3 climatic types exist: mild, mild - hot, cold climate. In these areas, the types of soil (clay, sandy, sandy- clay), the inclination rate of the slope (O 5- mountainous $30-45^{0}$; E 6- steep slope $\left.>45^{0}\right)$ are noted. 


\section{HIER A R C H IC A L C L USTER A N A L Y S IS}

\section{Dendrogram using Ward Method}

Labe 1

C A S E

L. cyaneus K20

L.cyaneus E1

L.pallescens D6

L. sphaericus E5

L. sphaericus M2

L. sphaericus K9

L. sphaericus ST1

L.laxiflorus ST2

L.laxiflorus ST2

L.laxiflorus E5

L.roseus ST1

L. cicera

L. cicera K9

L. cicera B2

L. annuus K13

L. annuus M5

L.pratensis $\mathrm{Z7}$

L.pratensis K19

L.pratensis E8

L.pratensis E2

L. tuberosus Z5

L. tuberosus K19

L. tuberosus D6

L. tuberosus Z8

L.tuberosus 21

L. aphaca K3

L. aphaca K4

L. aphaca E5

L. aphaca M1

L. aphaca

L. aphaca A8

L.miniatus E5

L.miniatus D3

L.miniatus E2

L.miniatus $\mathrm{Z} 11$

L.hirsutus G5

L.hirsutus Ab1

L.hirsutus E5

L.hirsutus A2

L.hirsutus

L.hirsutus B1

L.hirsutus $\mathrm{Z1}$

L.hirsutus $\mathrm{K} 6$

L.hirsutus D6

L.hirsutus M5

L.hirsutus A6

L.hirsutus M6

\section{Rescaled Distance Cluster Combine}
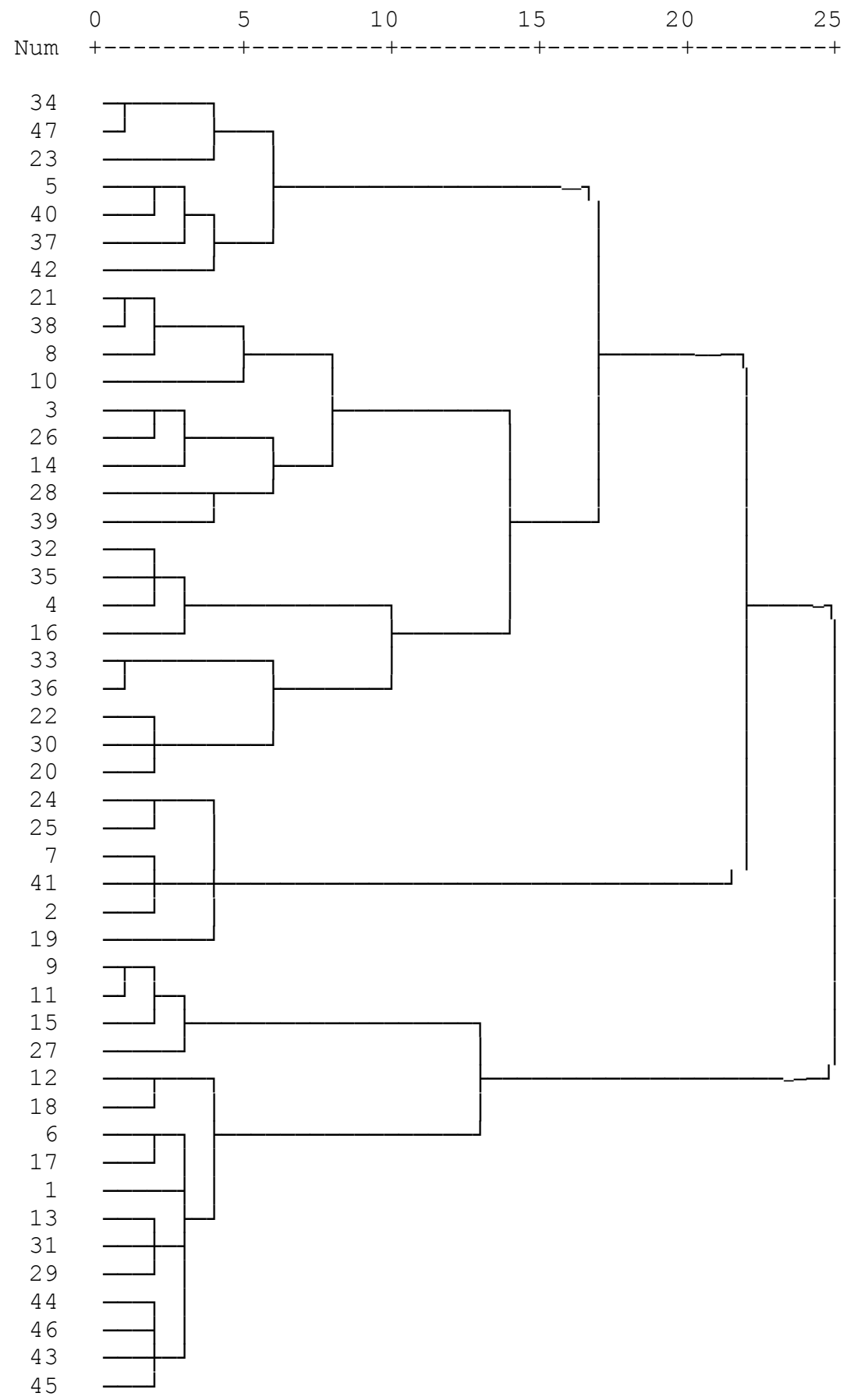

Fig. 2: Single Integrated Cluster Analysis of morhphological signs in Lathyrus species. 
The sixth cluster is divided into 5 subclusters: the first subcluster includes L. hirsutus (Bilasuvar, Absheron regions), the second subcluster includes L. hirsutus (Khizi, Imishli regions), the third subcluster includes L. hirsutus (Zagatala region), the fourth subcluster includes L. hirsutus (Lerik, Gabala, Aghdash regions), and the fifth subcluster includes L. hirsutus (Masalli region - Tekle, Gizilagaj). This species is included in the Lathyrus section (Shehadeh, 2011; Kupicha, 1974).

The L. hirsutus species included in the sixth cluster is mesophyte. This species is annual (Serebryakov, 1964). L. hirsutus species is found in low mountain ranges (Prilipko, 1954). In this cluster there are 4 climatic types: mild-hot semidesert and dry desert climate with dry summers, mild climate, mild - hot climate in which precipitation is equally distributed, mild - warm and dry. Here the types of soil (clay, clay - gravel, sandy, sandy- clay), the inclination rate of the slope (L 2 - flat $0^{0}-3^{0}$; O 5- mountainous $30-45^{0}$; E 6- steep slope $>45^{\circ}$ ) are indicated.

Thus, the research of the biomorphological variability and ecological features of the 12 species that have been accumulated by us, dispersed in different regions of Azerbaijan and in various ecological conditions has shown that these species are more commonly found in the Greater Caucasus, Kura - Araz and Talysh botanic - geographical regions. They are dispersed mostly in the forests and subalpine meadows. In these areas, the variability of the climatic condition and soil cover has resulted in the well adaptation of the Lathyrus species in these areas.

\section{References}

Asgarov, A. M., 2011. Concept of Azerbaijan's Flora. Baku, Elm, 204p.

Asgarov, A. M., 2016. The Plant World of Azerbaijan. Teas Press, Baku. 444p.

Asmussen, C., Liston, A., 1998. Chloroplast DNA characters, phylogeny and classification of Lathyrus (Fabaceae). Am. J. Bot. 85, 387-401. Badr, S. F., 2007. Karyotype analysis and chromosome evolution in species of Lathyrus (Fabaceae). Pak. J. Biol. Sci. 10(1), 49-56.

Bassler, M., 1973.Subgenus Lathyrus sect. Orobus in Eurasia. Feddes Rep. 84, 329-447.

Bojnansky, V., Fargasova, A., 2007. Atlas of seeds and fruits of Central and East - European Flora, Springer. 961p.

Chefranova, Z.V., 1971. System summary of the species Lathyrus L. News Syst. Higher Plants. (L), T.8, pp. 191-201.

Chefranova, Z.V., 1987. The Flora of Euro.part of the USSR. Publishing house "Science", T.VI, pp.147-170.

Cherepanov, S.K., 1995. Vascular Plants in Russia and Neighboring Countries. S.Petersburg: Publishing house "World" and the family-95, pp. 472-474

Davis, P. H. 1979. Lathyrus L. In: Davis P. H. ed. Flora of Turkey and East Aegean Islands. Edinburgh University Press. pp.328-369.

Fedchenko, B.A., 1948. Lathyrus sativus. Flora of the USSR. M., L.: Publishing House of the USSR Academy of Sciences, T. XIII. pp.479520.

Grossheim, A.A., 1952. Species Lathyrus L. Flora of the Caucasus. M.- L., t.V. pp.400-412

ILDIS. 2010. International Legume Database and Information Service, http://www.ildis.org/

Karyagin, I. I., 1954, In Fl. Azerbaijan. The genus Lathyrus L. et Orobus L. Baku: AN Azerbaijan SSR, Vol. V, pp.513-533

Kenicer, G., 2008. An introduction to the genus Lathyrus L. Curtis's Bot. Mag. 25(4), 286-295.

Kupicha, E. K., 1974. Taxonomic Studies in the Tribe Vicieae (Leguminosae). Doctoral thesis, University of Edinburgh. 588p.

Kupicha, E. K., 1983. The infragenetic structure of Lathyrus. Notes from the Royal Botanic Garden Edinburgh, 41, 209-244.

Leht, M., 2009. Phylogeny of Old World Lathyrus L. (Fabaceae) based on morphological data. Feddes Rep. 120(1-2), 59-74.

Lewis, G., Schrire, B., Mackinder, B. and Lock, M.,2005.Legumes of the World. Royal Botanic Gardens, Kew. 577 p.

Magulaev, A. U., 2005. Species Lathyrus L. (Fabaceae Lindl.) In the Flora of the Northern 
Caucasus. Bull. Stavropol State Univ. 42, 4450.

Maxted, N., Goyder, J., 1988. A new species of Lathyrus sect. Lathyrus (LeguminosaePapilionoideae) Turkey. Kew Bull. 43, 711-714.

Prilipko, L. İ., 1954. Forest Vegetation of Azerbaijan. Baku, 488p.

Raunkiaer, Ch., 1937. Plant Life Forms. Clarendon Press, Oxford. 104 p.

Sarker, A., Robertson, L.D., Abd El Moneim, A.M., Campbell, C. G., 1997. Lathyrus species: Conserved germplasm resources, priorities for collection and future prospects. In: Proceedings of International Food Legume Research Conference III, Adelaide, Australia.

Serebryakov, I.G., 1964. Life forms of higher plants and their study. In: Field Geobotany. Izd. Akad. Nauk SSSR, Moscow \& Leningrad. 3, pp.146208.

Shehadeh, A. A., 2011. Ecogeographic, Genetic and Taxonomic Studies of the Genus Lathyrus L. Doctoral thesus, University of Birmingham, 401p.

www.deren-grad.ru/ekologiya/ekologicheskiegruppy-vidov-rastenii.html

Yakovlev, G.P., Sytin, A.K., Roskov Yu, R., 1996. Legumes of Northern Eurasia. Royal Botanic Garden, Kew. pp. 527-547.

Yamamoto, K., Fujiware, T., Blumenreiett, L. D., 1984. Karyotypes and morphological characteristics of some species in the genus Lathyrus L. Jap. J. Breed. 34, 273-284.

\section{How to cite this article:}

Allahverdiyeva, G. F., Asgarov, A. M., 2018. Distribution and eco-biological research of Lathyrus species in Azerbaijan. Int. J. Curr. Res. Biosci. Plant Biol. 5(5), 8-16.

doi: https://doi.org/10.20546/ijcrbp.2018.505.002 